\title{
КВАЛИФИКАЦИЯ ОБЪЕКТОВ ТРУБОПРОВОДНОГО ТРАНСПОРТА КАК НЕДВИЖИМОГО ИМУЩЕСТВА
}

\begin{abstract}
Аннотация: Автором рассмотрено понятие имущественного комплекса, в такэе основные виды имущественных комплексов, включая предприятие, линейный объект, производственно-технологический комплекс. В данной статье сделана попытка отнесения объектов трубопроводного транспорта к объектам недвижимости, а именно к производственно-технологическому комплексу. Отраслевое законодательство и правоприменительная практика признают трубопроводы в качестве объекта недвижимости. Помимо неразрывной связи с землей, объекты трубопроводного транспорта можно рассматривать как недвижимость в силу достаточно высокой стоимости, по аналогии с иными видами транспорта.
\end{abstract}

Ключевые слова: Юриспруденция, недвижимость, имущуество, комплекс, предприятие, линейный объект, производство, технология, трубопровод, транспорт

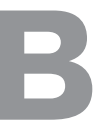
ажным является вопрос о возможности квалифицировать магистральные трубопроводы в качестве недвижимых вещей.

Законодательство выделяет имущественные комплексы как особые объекты гражданских прав, это связано с тем, что в настоящее время существует множество предприятий, деятельность которых охватывает различные сферы в экономике. К таким предприятиям можно отнести тех, что осуществляют свою деятельность, например, в нефтяной и газодобывающей промышленности, в состав которых входит множество совокупностей отдельных объектов как движимых так недвижимых, имущественных и неимущественных прав и обязанностей.

Целью данной статьи является вопрос о возможности квалифицировать магистральные трубопроводы в качестве недвижимых вещей в смысле ст. 130 ГК РФ. Отраслевое законодательство и правоприменительная практика признают трубопроводы в качестве объекта недвижимости. Помимо неразрывной связи с землей, объекты трубопроводного транспорта можно рассматривать как недвижимость в силу достаточно высокой стоимости, по аналогии с иными видами транспорта룰.

Представляется целесообразным рассмотреть понятие имущественный комплекс, а также его виды, чтобы определить являются ли объекты трубопроводного транспорта недвижимостью и к какому именно виду их следует отнести.

Прежде всего, хотелось рассмотреть общее понятие это имущественный комплекс, который в настоящее время является спорным объектом в современной цивилистике.

\footnotetext{
${ }^{1}$ Гудков И.В. Транспортировка газа в России: текущее состояние и перспективы нормативно-правового регулирования. Нефть, Газ и Право. №3 2009г. С.37
}

\section{1. Понятие имущественного комплекса.}

Действующий Гражданский кодекс РФ упоминает термин имущество в разных случаях с различным по объему содержанием, при этом нигде в кодексе не дано определения данного понятия, раскрывавшего его содержание и указывавшего на его атрибутивные признаки. В ст. 128 ГК РФ, определяющей виды объектов гражданских прав, закреплен объем имущества, который в науке принято называть полным активом имущества, а именно вещи и имущественные права. Статья 130 ГК РФ, определяя недвижимое имущество, ограничивает его состав только вещами. Из анализа норм Гражданского кодекса РФ путем строго формального толкования невозможно определить, какие именно объекты включаются в состав имущества. Нормы иных законодательных актов также не дают однозначного перечня включаемых в состав имущества объектов.

В целом можно признать, что гражданское законодательство даже в случаях, когда им предусматривается наиболее узкий круг видов имущества, не исключает из данного круга иные виды имущества. В современном российском гражданском праве как таковое понятие имущества не определяется. Некоторое представление о нем дается путем перечисления элементов, в него входящих. И через это перечисление раскрывается понятие имущества, так как определения отдельных составляющих имущества имеются, и если хотя бы не в законодательстве, то доктриной уже давно и довольно подробно данные определения разработаны. Так как, формулируя ст. 128 ГК РФ, законодатель произвел не определение понятия имущество, а его деление. Доктрина идет по тому же пути, что и законодатель, не определяя понятия имущество, а 


\section{Право и политика $4(160) \cdot 2013$}

ограничиваясь лишь перечислением его элементов, определяя эти элементы.

В нормативно-правовых актах, а также в актах официального толкования законодательства встречаются лишь определения и упоминания частных случаев имущественных комплексов, отдельных его видов, таких как предприятие, инвестиционный фонд, система газоснабжения, газораспределительная система и т.п. Понятие существует лишь на доктринальном уровне, например, Е.А. Суханов ${ }^{2}$ определяет имущественный комплекс как «особый объект гражданских прав, комплекс взаимосвязанных недвижимых и движимых вещей, используемых по общему назначению как единое целое».

Имущественный комплекс представляет собой не случайный набор отдельных видов имущества, а определенную, находящуюся в системе совокупность имущества, которое используется по общему назначению.

Для раскрытия понятия имущественного комплекса необходимо рассмотреть составляющие элементы данного понятия, через которые оно и определяется. А именно понятие имущества и понятие комплекса. Понятие имущества традиционно раскрывается через перечень объектов гражданских прав, содержащийся в ст. 128 ГК РФ. Некоторые авторы даже склонны отождествлять понятия объектов гражданских прав и имущества. Так C.А. Степанов раскрывает объем понятия имущества, в частности, через виды объектов гражданских прав ${ }^{3}$.

Попытаемся определить понятие имущества, исходя из имеющихся законодательных и доктринальных посылок. Имущество является объектом гражданских прав. Данные объекты перечислены в ст. 128 ГК РФ и разделены на относительно самостоятельные группы, а именно: 1) имущество; 2) работы и услуги; 3) информация; 4) интеллектуальная собственность; 5) нематериальные блага. Вещами в гражданском праве признаются материальные, физически осязаемые объекты, имеющие экономическую форму товара ${ }^{4}$.

Системный анализ норм Гражданского кодекса РФ позволяет прийти к выводу о том, что предметом гражданского оборота выступает именно имущество. Нематериальные блага не могут быть предметом оборота в силу естественных свойств данных благ. Работы и услуги, являющиеся процессом, сами по себе также не могут участвовать в обороте. Вещи же и имущественные права и обязанности по общему правилу могут свободно переходить от одного участника гражданских отношений

${ }^{2}$ Суханов Е.А. Актуальные вопросы гражданского права // ЭЖЮрист. 1999. N 40.

${ }^{3}$ Степанов С.A. Имущественные комплексы в российском гражданском праве. М., 2004. С. 77.

${ }^{4}$ Гражданское право: В 2 т. Том 1. Отв. ред. Е.А. Суханов. М., 2000. C. 300. к другому. Возможность участия в гражданском обороте рассматриваемых объектов обусловлена принципиальной возможностью определения стоимости любого объекта имущественной группы. Поэтому возможность денежной оценки является необходимым признаком для отнесения того или иного объекта к имуществу. Таким образом, признаками, по которым часть объектов гражданских прав объединяется в группу имущества, являются: 1) принципиальная возможность самостоятельно, непосредственно участвовать в товарно-денежном обороте; 2) возможность денежной оценки данных объектов.

Исходя из вышеизложенного, можем попытаться определить понятие «имущество». Имуществом является группа объектов гражданских прав, которые могут в силу своих естественных свойств участвовать в товарно-денежном обороте и которые могут быть оценены в денежной форме.

Теперь обратимся к понятию «комплекс». Данное понятие не имеет какого-либо законодательного определения, закрепления его основных свойств или указания на его основные признаки. Очевидно, что какого-то специального правового значения данное понятие не имеет. В Толковом словаре русского языка С.И. Ожегова и Н.Ю. Шведовой дано следующее толкование данного слова: «комплекс - совокупность, сочетание чего-нибудь ${ }^{5}$ ». Таким образом, комплекс представляет собой определенную группу элементов, объединенных логической связью. Раз для объединения элементов необходима некоторая связь, то каждый элемент способен к самостоятельному существованию вне комплекса. Элементы комплекса могут иметь совершенно разную природу или же быть предметами, явлениями, процессами одного порядка. Главное, чтобы при объединении их определенной связью свойства каждого из них и выполняемые ими функции позволяли и содействовали выполнению функций комплекса. При этом каждый элемент комплекса, хотя и способен к самостоятельному существованию, но не способен к выполнению функций всего комплекса, в связи с чем комплекс представляет собой самостоятельный предмет, процесс или явление, отличный от элементов, его составляющих, и от других предметов, процессов, явлений. Комплекс «(лат. complexus связь, сочетание) совокупность предметов, действий, свойств или явлений, составляющих одно целое, охватывающих группу чего-нибудь» ${ }^{6}$.

Таким образом, комплекс представляет собой совокупность определенных элементов, объединенных определенной связью, образующую единое целое и являющуюся объектом наибольшей степени общности эле-

${ }_{5}^{5}$ Ожегов С.И., Шведова Н.Ю. Толковый словарь русского языка: 80000 слов и фразеологических выражений. М., 1994. С. 288.

${ }^{6}$ Новейший словарь иностранных слов и выражений. М., 2005. Ст. 419 
ментов, входящих в данную совокупность ${ }^{7}$. На основании предложенных нами определений понятий «имущество» и «комплекс» попробуем определить понятие «имущественный комплекс». Имущественный комплекс - это совокупность объектов гражданских прав, способных в силу своих естественных свойств к участию в товарноденежном обороте, и в отношении которых может быть определена денежная оценка, объединенных определенной связью, образующая единый объект гражданских прав, относящаяся к отдельной группе видов имущества ${ }^{8}$.

Следовательно, можно придти к выводу, что имущественный комплекс - это объект особого рода, поскольку в его состав наряду с вещами включаются права и обязанности, а также отдельные виды вещей, которые без их переоборудования не могут использоваться самостоятельно.

Другими словами, имущественный комплекс - это объект качественно более высокого уровня, отражающий новый виток в развитии объектов гражданских прав 9 . Имущественный комплекс в целом - это настолько специфический и уникальный объект гражданского права, что все составляющие его элементы нельзя строго и бесспорно выделить в отдельные группы, виды и категории. ${ }^{10}$.

Все взгляды о правовой природе имущественного комплекса можно условно свести к следующим :

Первый подход - имущественный комплекс это особая разновидность вещей. Этот подход распадается на взгляды тех специалистов, которые полагают, что имущественные комплексы одновременно и недвижимость и сложная вещь (А. Грибанов $\left.{ }^{11}\right)$. И тех, кто считают, что имущественные комплексы являются только сложной вещью, не попадающей в чистом виде под правовой режим недвижимости.

Второй подход ${ }^{12}$ обосновывают ученые, которые видят в имущественных комплексах объект обязательственных прав ${ }^{13}$.

\footnotetext{
${ }^{7}$ Словарь иностранных слов. Под ред. И.В. Лехина и Ф.Н. Петрова M. 1954. C. 343.

${ }^{8} \mathrm{http}: / /$ www.kmcon.ru/main/articles/jurist/jurist_3022.html

9 Лаптева, А. М. Имущественные комплексы в коммерческом обороте :автореферат диссертации на соискание ученой степени кандидата юридических наук. СПб.,2010.

${ }^{10}$ Улььбина Т.С. Предприятие как имущественный комплекс объект гражданско-правовых отношений. // Современное право, 2006, № 8 .

${ }^{11}$ Грибанов А. Хозяйство и право, №7, 2003, стр. 69.

${ }^{12}$ Романов О.Е. Предприятие и иные имущественные комплексы как объекты гражданских прав: Дис. ... канд. юрид. наук. М., 2003. C. 227.

${ }^{13}$ Романов О. Государственная регистрация прав на недвижимость и сделок с недвижимым имуществом: некоторые вопросы правоприменения. Хозяйство и право № 8, 1998 г. стр. 46-50.
}

И третий подход разделяют авторы, рассматривающие имущественные комплексы как особые объекты, которые не могут быть отнесены ни к одному из традиционных видов объектов гражданских прав ${ }^{14}$.

\section{2. Понятие предприятия}

Целью исследования в данном параграфе является вопрос о возможности отнесении объектов трубопроводного транспорта к таким объектам недвижимости как предприятие. По мнению И.В. Гудкова объекты трубопроводного транспорта относят не к такой категории недвижимости, как «здания, сооружения», а в силу их комплексного состава квалифицируют как предприятия - имущественные комплексы, являющиеся недвижимостью в соответствии со статьей 132 ГК РФ.

Наиболее распространенной разновидностью имущественных комплексов является предприятие.

Определение предприятия как объекта гражданского оборота дано в Гражданском кодексе РФ согласно, которому, под предприятием как объектом прав признается имущественный комплекс, используемый для осуществления предпринимательской деятельности. Предприятие в целом как имущественный комплекс признается недвижимостью» (ст.132 ГК РФ).

Для того, чтобы определить относятся ли объекты трубопроводного транспорта к предприятиям, следует не только дать исчерпывающее толкование приведенного в статье 132 ГК РФ понятия, но и определить его характеристику исходя из совокупности различных видов объектов гражданских прав, входящих в его состав. В комментарии к ГК РФ под редакцией О.Н. Садикова в понятие предприятия включены следующие признаки:

1) единый имущественный комплекс, включающий все виды имущества, предназначенные для осуществления деятельности;

2) это только такой имущественный комплекс, который используется для осуществления предпринимательской деятельности.;

3) совершение сделок с предприятием не влечет прекращения производственной или иной предпринимательской деятельности, которая осуществлялась предыдущим владельцем, т.е. объектом выступает имущественный комплекс «на ходу».

4) при совершении сделок с имущественным комплексом юридического лица оно не прекращает свою деятельность в качестве субъекта гражданского права. Если юридическое лицо ликвидируется как субъект гражданского права, предприятие является уже не единым имущественным комплексом, а лишь отдельными видами имущества;

\footnotetext{
${ }^{14}$ Комментарий к Гражданскому кодексу РФ. Части 1-4 / Под ред. Степанова С.А. - 2009.
} 


\section{Право и политика $4(160) \cdot 2013$}

не входят в него и долги юридического лица ${ }^{15}$. Подобные признаки выделяет и М.Г. Пискунова, обобщая понятие, данное Гражданским кодексом РФ ${ }^{16}$. Несколько иначе раскрывает понятие «предприятие» Шершеневич Г.Ф. как «совокупность личных и имущественных средств, соединенных для достижения известной хозяйственноторговой цели по определенному плану» ${ }^{17}$.

Предприятие как объект имущественных прав, как объект гражданского оборота является не просто абстрактным набором «вещей» или их совокупностью. Предприятие - прежде всего имущественный комплекс, в состав которого входят наряду с недвижимостью и движимостью входят обязательственные права требования и пользования, обязанности, а также некоторые исключительные права - на обозначения, индивидуализирующие предприятие, его продукцию, работы и услуги, другие исключительные права ${ }^{18}$.

Следует так же согласиться с мнением В. Н. Табашникова, что «имущественный комплекс, используемый без цели извлечения прибыли, не образует предприятия. Используемый же комплекс коммерческой организацией в целях извлечения прибыли, уже является предприятием ${ }^{19}$ ». «Целевое предназначение имущественного комплекса - характерная черта и особенность объекта прав в виде предприятия ${ }^{20}$. Следовательно, только являясь действующим единым технологичным комплексом, тот или иной объект может быть признан предприятием как имущественным комплексом ${ }^{21}$. В то же время иные комплексы недвижимых и движимых вещей, не задействованных в предпринимательской деятельности, предприятием не являются ${ }^{22}$.

Предприятие как имущественный комплекс является сложной вещью. Данная классификация предприятия как сложной вещи предполагает, что действие сделки, предметом которой является предприятие, распространяется на все его составные части. Данная норма права является диспозитивной, а потому договором сторон может быть

${ }^{15}$ Комментарий к Гражданскому кодексу РФ. - М. «Инфра-М», 1999, комментарий к ст. 132.

${ }^{16}$ Государственная регистрация прав на недвижимость. Под. ред. Кирсанова А.Р. - М. Ось - 89, 2003 г., стр. 283.

${ }^{17}$ Шершеневич Г Ф. Учебник торгового права - М., 1994, с.70.

${ }^{18}$ Суханов Е. А. // Учебник Гражданского права, Том I «Бек», М., 1998 C. 306

${ }^{19}$ Табашников В. Н. // Журнал «Законодательство» №9, 1998. С. 6

${ }^{20} \mathrm{http} / / /$ www.bibliofond.ru/view.aspx?id=11914

${ }^{21}$ Хозяйство и право, №7, 2003 г., стр. 69, а также Витрянский В.В. Договор купли-продажи и его отдельные виды. - М. Статут. 1999. - стр. 266.

${ }^{22}$ Кирсанов А.Р. Система государственной регистрации прав на недвижимое имущество и сделок с ним в Российской Федерации. - Москва, издательство «Палеотип», 2002. предусмотрено иное: исключение некоторых вещей, обычно входящих в состав «сложной вещи ${ }^{23} »$.

Доктрина гражданского и торгового права западноевропейских стран, раскрывая понятие «предприятие», выделяет отдельные элементы имущественного комплекса предприятия - материальные и нематериальные ${ }^{24}$.

Как указывает С.А. Степанов, «по ГК РФ вещный момент в имущественном комплексе имеет или, во всяком случае, должен носить преобладающий и даже подчиняющий удельный вес ${ }^{25}$. Более того, законодатель прямо исходит не только из вещного характера предприятия, но непосредственно и, казалось бы, безоговорочно расставляет акценты: предприятие в целом как имущественный комплекс признается недвижимостью ${ }^{26}$ » .

Необходимо отметить и иную точку зрения на предприятие как имущественный комплекс. О.Е. Романов отмечает, что предприятие - это все имущество, выражающее отдельный промысел предпринимателя. В данном случае можно говорить о том, что все принадлежащее лицу имущество, с помощью которого осуществляется деятельность по извлечению прибыли в какой-либо отрасли, необходимо считать единым предприятием, что нецелесообразно исходя из интересов гражданского оборота ${ }^{27}$.

Некоторые правоведы, рассматривая понятие обособленного имущества в определении юридического лица (ст. 48 ГК РФ), приходят к выводу о возможности создания и участия в экономическом обороте юридического лица, вообще не обладающего какими-либо вещными правами. Имущество юридического лица может состоять в деньгах на счетах, в правах так называемой интеллектуальной собственности и т.П., а оборудование оно может арендовать ${ }^{28}$ ». Рассматривая данную точку зрения, представляется невозможным отнести объекты трубопроводного транспорта к предприятию.

Следовательно, предприятие может выступать в качестве объекта договора либо как имущественный комплекс, объединяющий вещи и имущественные пра-

\footnotetext{
${ }^{23}$ Брагинский М. И. Комментарий части первой Гражданского кодекса Российской Федерации // М. 1995. С 208

${ }^{24}$ Гражданское и торговое право зарубежных капиталистических стран / Под ред. Е.А. Васильева. М., 1993. С. 113.

${ }^{25}$ Степанов Д.И. Проблемы законодательства о юридических лицах // Журнал российского права. 2002. N 10. С. 43

${ }^{26}$ Степанов C.A. Предприятие как имущественный комплекс по Гражданскому кодексу Российской Федерации // Актуальные проблемы гражданского права / Под ред. С.С. Алексеева. М., 2000. C. 49.

${ }^{27}$ Романов O.E. Предприятие и иные имущественные комплексы как объекты гражданских прав: Дис. ... канд. юрид. наук. М., 2003. C. 227.

${ }^{28}$ Рахмилович В.A. О достижениях и просчетах нового Гражданского кодекса Российской Федерации // Государство и право. 1996.
} N 4. C. 122. 
ва, либо как имущественный комплекс, существующий только как определенная совокупность имущественных прав. Предприятие как имущественный комплекс, состоящий только из вещей, ни теоретически, ни практически существовать не может ${ }^{29}$.

Как отмечает А. Грибанов, «конкретный круг объектов интеллектуальной деятельности, входящих в состав предприятия - имущественного комплекса, не может быть определен достаточно полно в теоретическом отношении. Объекты интеллектуальной собственности характерны и специфичны для каждого участника предпринимательского оборота, зависят от предмета деятельности субъекта, занимаемого им места в экономической сфере, характера и оснований отчуждения от него в качестве предмета какой-либо гражданско-правовой сделки части имущества в виде предприятия ${ }^{30} \gg$.

Особое место занимает фирменное наименование ввиду особой значимости этой составляющей для имущественного комплекса в целом и дискуссионности вопроса о правомерности включения в компонент предприятия. Обоснованной представляется точка зрения авторов, относящих фирменное наименование к составу имущественного комплекса и признающих тем самым возможность его участия в предпринимательском обороте. Показательно мнение А. Грибанова: «Фирменное наименование юридического лица, безусловно, является средством, которое наряду с другими используется юридическим лицом в предпринимательской деятельности и поэтому является неотъемлемым нематериальным элементом предприятия, принадлежащего данному юридическому лицу ${ }^{31} »$.

В. Бузанов делает вывод, что, говоря о праве на фирменное наименование, российский законодатель имеет в виду тот «невесомый элемент» имущественного комплекса коммерческой организации, который материализуется в виде разницы между балансовой стоимостью всех ее активов и обязательств и той реальной ценой, которую уплачивает покупатель «в ожидании будущих экономических выгод ${ }^{32} \gg$.

Наиболее рациональным является мнение С.А. Степанова, который для обозначения указанного явления применяет понятие «совокупность устоявшихся предпринимательских связей». Эта совокупность не только гарантирует сбыт (клиентуру) результатов хозяйственной

${ }^{29}$ Овчинникова К.Д. Предприятие как объект гражданских прав в Германии, Италии, Франции, Англии и России: Дис. ... канд. юрид. наук. М., 2005. С. 50.

${ }^{30}$ Грибанов А. Предприятие: проблемы доктрины и законодательства // Хозяйство и право. 2000. N 5. С. 29.

${ }^{31}$ Грибанов $А$. Понятие предприятия в российском гражданском праве // Хозяйство и право. 2003. N 5. С. 65.

${ }_{32}$ Бузанов В. Право на фирму как объект гражданского оборота // Хозяйство и право. 2002. N 8. С. 48. деятельности предприятия, но и обеспечивает снабжение (организацию) всего дела в целом, причем независимо от вещной принадлежности самого имущественного комплекса тому или иному собственнику ${ }^{33}$.

«Введение категории «деловая репутация» является вполне обоснованным и логичным шагом законодателя в условиях рыночной экономики, когда каждый товаропроизводитель, участник имущественных отношений заинтересован в поддержании и упрочении своего имиджа надежного партнера, добросовестного контрагента и т.д ${ }^{34} »$.

Наряду с деловыми связями, деловая репутация подлежит имущественной оценке и, следовательно, как делает вывод К. Гасников, приобретает коммерческую значимость не только в совместной деятельности, но и в составе имущества предприятия ${ }^{35}$. В некоторых случаях деловую репутацию отделяют от шансов, т.е. возможностей предприятия иметь клиентов в будущем. Шансы определяют как оцененные в денежном выражении перспективы предприятия ${ }^{36}$.

Предприятие признается недвижимостью не в силу его прочной связи с землей, а по решению законодателя с целью распространения на него правового режима, устанавливаемого для недвижимого имущества. Если в состав предприятия будут входить только обособленные движимые вещи, а также имущественные права и обязанности, то предприятие также будет считаться недвижимым имуществом. Как отмечает О.М.Козырь ${ }^{37}$, отношение законодателя к предприятию как к особому объекту прав проявляется, «во-первых, чисто формально, предприятие не упоминается в определении недвижимости в статье 130 ГК, а «вводится» в статье 132 ,которая расположена после блока статей о недвижимости, во-вторых, по составляющим его элементам объект этот настолько неоднороден, что отнесение его к той или иной группе объектов может быть осуществлено только исходя из характеристики его как особого имущественного комплекса.

На основании изложенного можно сделать следующий вывод. Предприятие представляет собой единый и неделимый объект прав, используемый для осуществления предпринимательской деятельности, в состав которого входят материальные и нематериальные виды имущества. Таким образом, предприятие действительно является

\footnotetext{
${ }^{33}$ Степанов С.А. Указ. раб. С. 63.

34 Гражданское право: Учеб. для вузов / Под общ. ред. Т.Н. Илларионовой, Б.М. Гонгало, В.А. Плетнева. Ч. 1. М., 1998. С. 187.

${ }^{35}$ Гасников К. Деловая репутация в качестве вклада // ЭЖ-Юрист. 1999. N 38.

${ }^{36}$ Кулагин М.И. Государственно-монополистический капитализм и юридическое лицо // Избранные труды: Сборник. М., 1997. С.32

${ }^{37}$ Koзырь O.M. Недвижимость в новом Гражданском кодексе России (Гражданский кодекс России: проблемы, теория, практика. Под ред. А.К. Маковского. М. 1998. С. 280.
} 


\section{Право и политика $4(160) \cdot 2013$}

недвижимостью, но не в силу его связи с землей, а на основании определения его законом в качестве таково$г^{38}$. В литературе высказывалось мнение, что главным недостатком действующего законодательства следует признать отсутствие в нем четких признаков предприятия как объекта гражданских прав, которые отличали бы предприятие от иных сходных объектов, например, от других имущественных комплексов, которые в принципе можно использовать в предпринимательской деятельности ${ }^{39}$. Будучи объектом права, предприятия являются предметом различных сделок.

\section{3. Трубопровод как производственно-технологический комплекс. Особенности коллизионного регулирования объектов трубопроводного транспорта как объектов недвижимости.}

Особой разновидностью недвижимости являются комплексы взаимосвязанных недвижимых и движимых вещей, используемых по общему назначению как единое целое.

В Российской Федерации нередко предприятия как имущественные комплексы рассматривают в связи с другими сложными объектами: комплекс зданий и сооружений, протяженные объекты, производственно-технологические комплексы ${ }^{40}$.

Стоит отметить, что ни Федеральный закон от 21.07.1997 № 122-Ф3 «О государственной регистрации прав на недвижимое имущество и сделок с ним ${ }^{41} \gg$, ни Гражданский кодекс Российской Федерации, прямо не называли линейные объекты в качестве недвижимого имущества.

Отнесение к числу недвижимости линейных объектов и распространение на них соответствующего правового режима было связано с принятием в частности таких нормативно-правовых актов как Федеральный закон от 07.07.2003 № 126-Ф3 «О связи», Федеральный закон от 08.11.2007 № 257-Ф3 «Об автомобильных дорогах и о дорожной деятельности в Российской Федерации и о внесении изменений в отдельные законодательные акты Российской Федерации». Специфика линейных сооружений состоит в их достаточной протяженности и прохож-

\footnotetext{
38 Эрделевский А.М. Комментарий к Федеральному закону о государственной регистрации прав на недвижимое имущество и сделок с ним. М. 1999. С. 3

${ }^{39}$ Концепция гражданского законодательства о недвижимом имуществе. Под ред. В.В. Витрянского, О.М. Козырь, А.А. Маковской M. 2004. C. 43.

${ }^{40} \mathrm{http}: / /$ www.minjust.org/web.nsf/753c102460d12e01c2256b4100687 c72/79357d68c3634c11c225712a00356a63!OpenDocument

${ }^{41}$ Ф3 «О государственной регистрации прав на недвижимое имущество и сделок с ним» (принят ГД ФС РФ 17.06.1997) (ред. от 27.12.2009)
}

дении по значительному количеству земельных участков, имеющих различных собственников и правовой режим.

Для целей настоящего обобщения под линейными объектами понимаются инженерно-строительные объекты с технологическими устройствами, составляющими с ними единое целое или законченное функциональное единство, предназначенные для транспортирования жидкостей, газов, иных объектов, передачи энергии, сигнала. Федеральный закон от 21.12.2004 № 172-Ф3 «О переводе земель или земельных участков из одной категории в другую» упоминает трубопроводы в качестве линейный объектов. Градостроительный кодекс Российской Федерации (2004 г.) понимает под такими объектами сети инженерно-технического обеспечения, линии электропередачи, линии связи, трубопроводы, автомобильные дороги, железнодорожные линии. ${ }^{42}$.

Необходимо выделить сущностные характеристики ЛО. Первая характеристика заключена в самом термине «линейные», т. е. длина (протяженность) объекта намного превышает его ширину. Вторая характеристика - ЛО является сооружением. Третья и самая особенная характеристика - ЛО свойственна связь с землей, с земельными участками. Именно эта сущность определяет необходимость классификации ЛО в зависимости от связи с землей. Четвертая особенность - в их состав могут входить площадные объекты, технологически связанные с ЛО. Согласно характеристикам линейных объектов объекты трубопроводного транспорта без условно могут быть отнесены к линейным объектам, в связи с тем что полностью отвечают критериям протяженности, являются сооружением, объектам трубопроводного транспорта присуща связь с земельными участками. Еще одно узкое по кругу определение содержится в Федеральном законе от 31 марта 1999 года №69-Ф3 «О газоснабжении в Российской Федерации», система газоснабжения - имущественный производственный комплекс, состоящий из технологически, организационно и экономически взаимосвязанных и централизованно управляемых производственных и иных объектов, предназначенных для добычи, транспортировки, хранения, поставок газа; газораспределительная система - имущественный производственный комплекс, состоящий из организационно и экономически взаимосвязанных объектов, предназначенных для транспортировки и подачи газа непосредственно его потребителям (ст. 2). Как мы видим оно касается лишь объектов газоснабжения. Представляется возможным обобщить данное определение и применить его не только к объектам газоснабжения, но и нефтедобычи, объединив, таким образом, их в одну категорию - производственно технический комплекс. Следовательно, логически можно

\footnotetext{
${ }^{42}$ http://av-ue.ru/just.php?d=lineynoprotyajennye obekty.htm
} 
выделить следующую категорию имущественных комплексов - технически взаимосвязанные.

Если речь идет о технологическом комплексе, то он, прежде всего, объединен не только общими организационными задачами, но и в инженерно-техническом плане. Если проводить анализ единых производственно-технологических комплексов и предприятий как имущественных комплексов, то можно обнаружить определенные различия. Производственно-технический комплекс объединен функционально-технологически, он может являться сложной вещью, поскольку состоит из разнородных вещей, без которых он уже не будет способен выполнять своих функциональных задач. Предприятие как имущественный комплекс не обязательно может быть объединено функционально-технологически. Здесь связь объектов еще и правовая. То есть собственник произвольно включает в его состав те объекты, которые он посчитает нужными ${ }^{43}$. Этот критерий также позволяет не отождествлять объекты трубопроводного транспорта и предприятие.

Следует отметить, что в постановлении Президиума ВАС РФ от 26 сентября 2000 г. по делу N 3531/00 44 была дана попытка дать определение имущественному комплексу, состоящему из скважины минеральной воды и здания насосной станции, который и подпадает под упомянутые признаки технологического имущественного комплекса. Одновременно предлагается ввести в законодательство указанное понятие, которое обладало бы следующими признаками: 1. Объединение различных объектов движимого и недвижимого имущества их единым хозяйственным назначением; 2. Наличие в составе технологического имущественного комплекса земельного участка, на котором расположен иной объект недвижимости, входящий в имущественный комплекс; 3. Отсутствие в составе такого имущественного комплекса прав требования и долгов по обязательствам его собственника, которые при совершении сделки по отчуждению технологического комплекса могут передаваться новому собственнику по договоренности сторон путем уступки прав требования и перевода долга, совершаемых в обычном порядке.

\section{4. Вывод}

Таким образом, объекты недвижимости являются вещами, и как объекты права они объективны, постоянны, пространственно определены. Предприятия вещами не являются, и как объекты права они субъективны, изменчивы, могут быть пространственно не определены. Это и отличает трубопровод от предприятия. Следует придти к выводу, что трубопровод следует рассматривать как объ-

\footnotetext{
${ }^{43} \mathrm{http}: / /$ www.minjust.org/web.nsf/753c102460d12e01c2256b4100687 c72/79357d68c3634c11c225712a00356a63!OpenDocument

${ }^{44}$ Вестник ВАС РФ. 2002. N 10.
}

ект недвижимости, а именно технологически сложный объект отличный от предприятия.

В итоге, следует добавить, что в настоящее время законодатель не обременил себя выделением на виды имущественные комплексы. На основе вышеизложенного представляется необходимым выработать единое понятие «имущественный комплекс», объединяющее все вышеперечисленные определения, и разделить их на виды для точного выделения существенных признаков каждого из них для конкретного правового регулирования. Изучая правовые конструкции имущественного комплекса, возможно определить групповые сходства объектов, включающих в себя вещи, различные по своим свойствам. Можно выделить несколько понятий вышеперечисленных объектов ${ }^{45}$. Представляется, что очевидна необходимость определения еще и производственно-технологического комплекса, под которым следует понимать - совокупность объектов, используемых в производственной деятельности организации и обеспечивающих непрерывный производственный процесс, технологически и организационно связанных между собой гак, что исключение какого-либо объекта из состава ПТК ведет к невозможности, либо значительному уменьшению эффективности его использования, ПТК может являться объектом технического учета и объектом права ${ }^{46}$. В настоящий момент этот вопрос решается, путем внесения изменений в ГК РФ.

Одной из важнейших из планируемых новелл Проекта ГК является положение новой редакции п. 2 ст. 130 ГК РФ $\Phi^{47}$.

В соответствии с указанным пунктом недвижимой вещью, участвующей в обороте как единый объект, признается единый имущественный комплекс - совокупность объединенных единым назначением зданий, сооружений и иных объектов, неразрывно связанных физически или технологически.

Приведенное положение призвано упростить проблему отнесения к недвижимому имуществу таких нестандартных, но распространенных объектов, как линейные, а также иные объекты, единые с технологической точки зрения, но не относящиеся к традиционным зданиям, строениям и сооружениям.

В настоящее время существует несколько способов решения данной проблемы.

В отдельных случаях это делается в рамках отраслевого законодательства. Так, например, в силу п. 1 ст. 8 уже

\footnotetext{
${ }^{45}$ Гальцеева О.Д. Институт государственной регистрации прав на недвижимое имущество и ипотечное жилищное кредитование // Юрист Поволжья. 2004. №7-8. С. 51-52.

${ }^{46}$ О государственной регистрации прав на недвижимое имущество. Сборник №4. Самара 2002. стр. 90.

47 КонсультантПлюс: Правовые новости. Специальный выпуск «Комментарий к проекту изменений Гражданского кодекса Российской Федерации (Законопроект N 47538-6/3)»
} 


\section{Право и политика $4(160) \cdot 2013$}

упомянутого Федерального закона от 07.07.2003 N 126-Ф3 «О связи» линейно-кабельные сооружения связи являются недвижимым имуществом ${ }^{48}$.

\section{Библиография:}

1. Брагинский М. И. Комментарий части первой Гражданского кодекса Российской Федерации // М. 1995. С 208

2. Бузанов В. Право на фирму как объект гражданского оборота // Хозяйство и право. 2002. N 8. С. 48.

3. Васильев Е.А. Гражданское и торговое право зарубежных капиталистических стран. М., 1993. С. 113.

4. Витрянский В.В. Договор купли-продажи и его отдельные виды. - М. Статут.-1999.-стр. 266.

5. Гальцева О.Д. Институт государственной регистрации прав на недвижимое имущество и ипотечное жилищное кредитование // Юрист Поволжья. 2004. №7-8. С. 51-52.

6. Гасников К. Деловая репутация в качестве вклада // ЭЖ-Юрист. 1999. N 38.

7. Гражданское право: В 2 т. Том 1. Отв. ред. Е.А. Суханов. М., 2000. С. 300.

8. Гражданское право: Учеб. для вузов / Под общ. ред. Т.Н. Илларионовой, Б.М. Гонгало, В.А. Плетнева. Ч. 1. М., 1998. С. 187.

9. Грибанов А. Понятие предприятия в российском гражданском праве // Хозяйство и право. 2003. N 5. C. 65 .

10. Грибанов А. Предприятие: проблемы доктрины и законодательства // Хозяйство и право. 2000. N 5. С. 29.

11. Грибанов.А. Правовая природа предприятия - имущественного комплекса в праве России.Хозяйство и право, №7, 2003 г., стр. 69.

12. Гудков И.В. Транспортировка газа в России: текущее состояние и перспективы нормативно-правового регулирования. Нефть, Газ и Право. №3 2009г. С.37

13. Кирсанов А.Р. Государственная регистрация прав на недвижимость. М. Ось - 89, 2003 г., стр. 283.

14. Козырь О.М. Недвижимость в новом Гражданском кодексе России (Гражданский кодекс России: проблемы, теория, практика. Под ред. А.К. Маковского. М. 1998. С. 280.

15. Кирсанов А.Р. Система государственной регистрации прав на недвижимое имущество и сделок с ним в Российской Федерации. -Москва, издательство «Палеотип», 2002.

\footnotetext{
${ }^{48}$ п. 3 Положения об особенностях государственной регистрации права собственности и других вещных прав на линейно-кабельные сооружения связи, утвержденные Постановлением Правительства РФ от 11.02 .2005 N 68
}

16. Концепция гражданского законодательства о недвижимом имуществе. Под ред. В.В. Витрянского, О.М. Козырь, А.А. Маковской М. 2004. С. 43.

17. Кулагин М.И. Государственно-монополистический капитализм и юридическое лицо // Избранные труды: Сборник. М., 1997. С.32

18. Лаптева А. М. Имущественные комплексы в коммерческом обороте :автореферат диссертации на соискание ученой степени кандидата юридических наук. СПб.,2010.

19. Новейший словарь иностранных слов и выражений. М., 2005. Ст. 419

20. Овчинникова К.Д. Предприятие как объект гражданских прав в Германии, Италии, Франции, Англии и России: Дис. ... канд. юрид. наук. М., 2005. С. 50.

21. Ожегов С.И., Шведова Н.Ю. Толковый словарь русского языка: 80000 слов и фразеологических выражений. М., 1994. С. 288.

22. Рахмилович В.А. О достижениях и просчетах нового Гражданского кодекса Российской Федерации // Государство и право. 1996. N 4. С. 122.

23. Романов О.Е. Государственная регистрация прав на недвижимость и сделок с недвижимым имуществом: некоторые вопросы правоприменения. Хозяйство и право № 8, 1998 г. стр. 46-50.

24. Романов О.Е. Предприятие и иные имущественные комплексы как объекты гражданских прав: Дис. ... канд. юрид. наук. М., 2003. С. 227.

25. Словарь иностранных слов. Под ред. И.В. Лехина и Ф.Н. Петрова М. 1954. С. 343.

26. Степанов Д.И. Проблемы законодательства о юридических лицах // Журнал российского права. 2002. N 10. C. 43

27. Степанов С.А. Имущественные комплексы в российском гражданском праве. М., 2004. С. 77.

28. Степанов С.А. Предприятие как имущественный комплекс по Гражданскому кодексу Российской Федерации // Актуальные проблемы гражданского права / Под ред. С.С. Алексеева. М., 2000. С. 49.

29. Суханов Е.А. Актуальные вопросы гражданского права // ЭЖ-Юрист. 1999. N 40.

30. Суханов Е. А. // Учебник Гражданского права, Том I «Бек», М., 1998 С. 306

31. Табашников В. Н. // Журнал «Законодательство» №9, 1998. С. 6

32. Улыбина Т.С. Предприятие как имущественный комплекс - объект гражданско-правовых отношений. // Современное право, 2006, № 8.

33. Шершеневич Г Ф. Учебник торгового права - М., 1994, с.70.

34. Эрделевский А.М. Комментарий к Федеральному закону о государственной регистрации прав на недвижимое имущество и сделок с ним. М. 1999. С. 3 


\section{References (transliteration):}

1. Braginskiy M. I. Kommentariy chasti pervoy Grazhdanskogo kodeksa Rossiyskoy Federatsii // M. 1995. S 208

2. Buzanov V. Pravo na firmu kak ob'ekt grazhdanskogo oborota // Khozyaystvo i pravo. 2002. N 8. S. 48.

3. Vasil'ev E.A. Grazhdanskoe i torgovoe pravo zarubezhnykh kapitalisticheskikh stran. M., 1993. S. 113.

4. Vitryanskiy V.V. Dogovor kupli-prodazhi i ego otdel'nye vidy. - M. Statut.-1999.-str. 266.

5. Gal'tseva O.D. Institut gosudarstvennoy registratsii prav na nedvizhimoe imushchestvo i ipotechnoe zhilishchnoe kreditovanie // Yurist Povolzh’ya. 2004. №7-8. S. 51-52.

6. Gasnikov K. Delovaya reputatsiya v kachestve vklada // EZh-Yurist. 1999. N 38.

7. Gribanov A. Ponyatie predpriyatiya v rossiyskom grazhdanskom prave // Khozyaystvo i pravo. 2003. N 5. S. 65.

8. Gribanov A. Predpriyatie: problemy doktriny i zakonodatel'stva // Khozyaystvo i pravo. 2000. N 5. S. 29.

9. Gribanov.A. Pravovaya priroda predpriyatiya imushchestvennogo kompleksa v prave Rossii.Khozyaystvo i pravo, №7, 2003 g., str. 69.

10. Gudkov I.V. Transportirovka gaza v Rossii: tekushchee sostoyanie i perspektivy normativno-pravovogo regulirovaniya. Neft', Gaz i Pravo. №3 2009g. S.37

11. Kirsanov A.R. Gosudarstvennaya registratsiya prav na nedvizhimost'. M. Os' - 89, 2003 g., str. 283.

12. Kozyr' O.M. Nedvizhimost' v novom Grazhdanskom kodekse Rossii (Grazhdanskiy kodeks Rossii: problemy, teoriya, praktika. Pod red. A.K. Makovskogo. M. 1998. S. 280.

13. Kirsanov A.R. Sistema gosudarstvennoy registratsii prav na nedvizhimoe imushchestvo i sdelok s nim v Rossiyskoy Federatsii. -Moskva, izdatel'stvo «Paleotip», 2002.

14. Kulagin M.I. Gosudarstvenno-monopolisticheskiy kapitalizm i yuridicheskoe litso // Izbrannye trudy: Sbornik. M., 1997. S.32

15. Lapteva A. M. Imushchestvennye kompleksy v kommercheskom oborote :avtoreferat dissertatsii na sois- kanie uchenoy stepeni kandidata yuridicheskikh nauk. SPb.,2010.

16. Ovchinnikova K.D. Predpriyatie kak ob'ekt grazhdanskikh prav v Germanii, Italii, Frantsii, Anglii i Rossii: Dis. ... kand. yurid. nauk. M., 2005. S. 50.

17. Ozhegov S.I., Shvedova N.Yu. Tolkovyy slovar' russkogo yazyka: 80000 slov i frazeologicheskikh vyrazheniy. M., 1994. S. 288.

18. Rakhmilovich V.A. O dostizheniyakh i proschetakh novogo Grazhdanskogo kodeksa Rossiyskoy Federatsii // Gosudarstvo i pravo. 1996. N 4. S. 122.

19. Romanov O.E. Gosudarstvennaya registratsiya prav na nedvizhimost' i sdelok s nedvizhimym imushchestvom: nekotorye voprosy pravoprimeneniya. Khozyaystvo i pravo № 8, 1998 g. str. 46-50.

20. Romanov O.E. Predpriyatie i inye imushchestvennye kompleksy kak ob'ekty grazhdanskikh prav: Dis. ... kand. yurid. nauk. M., 2003. S. 227.

21. Stepanov D.I. Problemy zakonodatel'stva o yuridicheskikh litsakh // Zhurnal rossiyskogo prava. 2002. N 10. S. 43

22. Stepanov S.A. Imushchestvennye kompleksy v rossiyskom grazhdanskom prave. M., 2004. S. 77.

23. Stepanov S.A. Predpriyatie kak imushchestvennyy kompleks po Grazhdanskomu kodeksu Rossiyskoy Federatsii // Aktual'nye problemy grazhdanskogo prava / Pod red. S.S. Alekseeva. M., 2000. S. 49.

24. Sukhanov E.A. Aktual'nye voprosy grazhdanskogo prava // EZh-Yurist. 1999. N 40.

25. Sukhanov E. A. // Uchebnik Grazhdanskogo prava, Tom I «Bek», M., 1998 S. 306

26. Tabashnikov V. N. // Zhurnal «Zakonodatel'stvo» №9, 1998. S. 6

27. Ulybina T.S. Predpriyatie kak imushchestvennyy kompleks - ob'ekt grazhdansko-pravovykh otnosheniy. // Sovremennoe pravo, 2006, № 8.

28. Shershenevich G F. Uchebnik torgovogo prava - M., 1994, s.70.

29. Erdelevskiy A.M. Kommentariy k Federal'nomu zakonu o gosudarstvennoy registratsii prav na nedvizhimoe imushchestvo i sdelok s nim. M. 1999. S. 3 